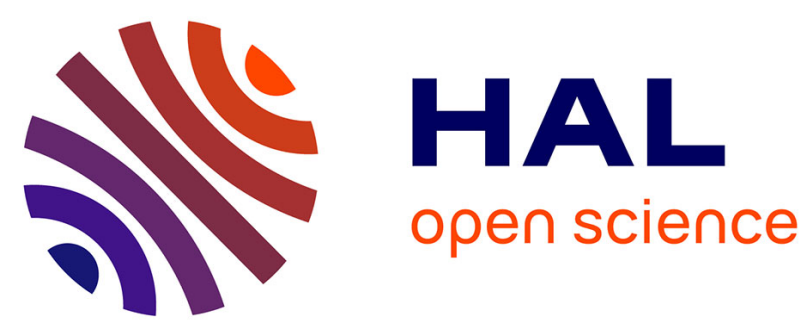

\title{
Identification, stress tolerance, and antioxidant activity of lactic acid bacteria isolated from tropically grown fruits and leaves
}

Amandine Fessard, Emmanuel Bourdon, Bertrand Payet, Fabienne Remize

\section{To cite this version:}

Amandine Fessard, Emmanuel Bourdon, Bertrand Payet, Fabienne Remize. Identification, stress tolerance, and antioxidant activity of lactic acid bacteria isolated from tropically grown fruits and leaves. Canadian Journal of Microbiology, 2016, 62, pp.550-561. 10.1139/cjm-2015-0624 . hal01399824

\section{HAL Id: hal-01399824 \\ https://hal.univ-reunion.fr/hal-01399824}

Submitted on 21 Nov 2016

HAL is a multi-disciplinary open access archive for the deposit and dissemination of scientific research documents, whether they are published or not. The documents may come from teaching and research institutions in France or abroad, or from public or private research centers.
L'archive ouverte pluridisciplinaire HAL, est destinée au dépôt et à la diffusion de documents scientifiques de niveau recherche, publiés ou non, émanant des établissements d'enseignement et de recherche français ou étrangers, des laboratoires publics ou privés. 
Identification, stress tolerance and antioxidant activity of lactic acid bacteria isolated from tropically-grown fruits and leaves

Amandine FESSARD ${ }^{(1)}$, Emmanuel BOURDON $^{(2)}$, Bertrand PAYET $^{(3)}$, Fabienne REMIZE $^{(1)^{*}}$

Affiliations :

(1) Université de La Réunion, UMR QualiSud, ESIROI, 2 rue J. Wetzell, Parc Technologique Universitaire, Sainte Clotilde, France

(2) Université de La Réunion, UMR DéTROI - Inserm U1188 Diabète athérothrombose Thérapies Réunion Océan Indien, Plateforme CYROI, Saint Denis de La Réunion, France

(3) Université de La Réunion, EA LCSNSA, rue René Cassin, Saint Denis de La Réunion, France

* Corresponding author: Fabienne Remize, Université de La Réunion, UMR QualiSud, ESIROI, 2 rue J.

Wetzell, Parc Technologique Universitaire, Sainte Clotilde, France

fabienne.remize@univ-reunion.fr; +262 692200785 


\section{ABSTRACT}

Out of six samples of tropically grown fruits and leaves, ten lactic acid bacteria belonging Leuconostoc, Weissella and Lactobacillus species were isolated and identified by $16 \mathrm{~S}$ gene sequencing and $(\mathrm{GTG})_{5}$ fingerprinting. Acidification kinetics determined from $\mathrm{BHI}$ broth cultures showed genus-related patterns. In particular, Weissella cibaria appeared to act as a potent acidifier. Tolerance to acid, oxidative or salt stress of isolates was highly variable and strain dependent. Isolate S14 (Leuconostoc pseudomesenteroides) growth was not affected by the presence of $0.05 \% \mathrm{H}_{2} \mathrm{O}_{2}$ while Lactobacillus spp. isolates (S17 and S29) were the most tolerant to $\mathrm{pH}$ 4.5. The growth of four isolates, S5 (Leuconostoc mesenteroides), S14 and S10 (Leuc. pseudomesenteroides) and S27 (W. cibaria) was not affected by $5 \% \mathrm{NaCl}$. Nutritional beneficial properties were examined through measurement of antioxidant activities of short-term fermented pineapple juice, such as LDL oxidation and polyphenol content, and through exopolysaccharide formation from sucrose. Two isolates, S14 and S27 increased antioxidant capacity of pineapple juice. The robust capacity of $W$. cibaria and of Leuc. pseudomesenteroides for vegetable lactic fermentation aimed to ameliorate food nutritional and functional quality was highlighted.

Keywords: diversity, Weissella spp., Leuconostoc spp., antioxidant, stress adaptation 


\section{INTRODUCTION}

Lactic acid bacteria (LAB) cover many different species, with very diverse physiological traits and ecology. They can be used as starters, probiotics, for ingredient biosynthesis or for bio-preservation. Lactic acid fermentation of fruits and vegetables has regained attention over the last decade due to the multiple health advantages related to the consumption of fruits and vegetables compared to animal products and to the fast growing demand of healthy foods by increasingly conscious consumers. When applied to table olives, cabbage for sauerkraut or kimchi production or small fruits for pickles, this simple and valuable biotechnology results in a safety increase, in prolonged shelf-life and in changes of nutritional and sensorial properties (Bourdichon et al. 2012; Hugenholtz 2013; Juodeikiene et al. 2012; Rodriguez et al. 2009). In particular, the effects of lactic acid fermentation on antioxidant activity of fruits and vegetables were investigated (Di Cagno et al. 2011, 2009; Filannino et al. 2013; Noumo et al. 2013; Othman et al. 2009; Park et al. 2011; Sun et al. 2009; Wu et al. 2011). Depending on the studies, a more or less marked decrease or increase in antioxidant activity and changes in phenolic compounds have been reported. The differential effects of lactic acid fermentation observed between studies can be explained by the diversity of substrates, fermentation protocols and analytical methods used in these studies, but also by the diversity of LAB. Edible fruits and leaves in warm-climate countries are often traditionally preserved as lactic fermented foods (Franz et al. 2014; Lan et al. 2013; Ng et al. 2011; Nguyen et al. 2013). In these cases, home-made products result from spontaneous fermentation or back-slopping (Lan et al. 2013; Liu et al. 2011; Oguntoyinbo et al. 2007) and fermentative bacteria originate from fruit phyllosphere and kitchen equipment. Spontaneous fermentation results from a competition between microorganisms where the most adapted ones will prevail. Hence, food fermentation processes are associated with several stresses, depending on the growth medium composition and other environmental conditions (Giraffa 2004; Serrazanetti et al. 2013). For these reasons, autochthonous bacteria, well-adapted to their ecological niche, are recognized as the most efficient to perform fermentation. 
In this study, we first aimed to assess the biotechnological diversity of LAB isolates from the surface of papaya, tomato or sliced cabbage grown under tropical warm-climate. A second objective was to select LAB for their future use as starter for healthy fermented fruit or vegetable juices. The Victoria cultivar of pineapple, produced in South West areas of Indian Ocean, recognized for its sensorial properties, was chosen as fermentation substrate. As bacteria ability to resist to acid juice and to maintain or increase antioxidant activity level is critical for fruit or vegetable fermentation, relevant phenotypic traits as growth yield, acidification rate, stress tolerance, antioxidant activity and exopolysaccharide formation were determined.

\section{MATERIALS AND METHODS}

\section{Biological materials}

LAB were isolated from tomatoes (Lycopersicon esculantum), sliced white cabbage (Brassica oleacera var. capitata) and papaya (Carica papaya) grown in Reunion Island and isolates were stored at $-80^{\circ} \mathrm{C}$. These food materials were obtained from local markets and stored for $24 \mathrm{~h}$ at $4^{\circ} \mathrm{C}$ in sterile bags before analysis. Sliced cabbage was directly used, whereas tomato and papaya were cut: a $1 \mathrm{~cm}$-thick slice in the median part of the fruit was cut with a sterile scalpel and $25 \mathrm{~g}$ were sampled from the center of the slice to the external arc of circle. For isolation, $25 \mathrm{~g}$ sample was mixed with $25 \mathrm{~g}$ buffered peptone water in a stomacher for $1 \mathrm{~min}$, and then serial decimal dilutions in the same buffer were spread on selective agar. All isolates share the ability to grow on MRS agar with cycloheximide and are catalase negative. Lactobacillus plantarum DSM2601 was used as reference strains for all experiments.

A single batch of commercial pasteurized pineapple juice (Pur Jus Ananas Victoria de la Réunion, ALBIUS) was used for all experiments.

\section{Culture conditions}

Isolates and DSM2601 were grown on MRS agar at $37^{\circ} \mathrm{C}$ for $72 \mathrm{~h}$. 
For isolate reactivation, one or two colonies or a loop of $-80^{\circ} \mathrm{C}$ stock were suspended in $9 \mathrm{~mL}$ of $\mathrm{BHI}$ (Brain Heart Infusion) and incubated at $37^{\circ} \mathrm{C}$ for $48 \mathrm{~h}$. Afterwards cultures were homogenized by vortex and $0.2 \mathrm{~mL}$ of the medium was used to inoculate $9 \mathrm{~mL}$ of $\mathrm{BHI}$. This pre-culture was incubated at $37^{\circ} \mathrm{C}$ for $72 \mathrm{~h}$. After $72 \mathrm{~h}$, another tube of $\mathrm{BHI}$ broth was inoculated from this pre-culture and incubated at $37^{\circ} \mathrm{C}$ for $24 \mathrm{~h}$. In $\mathrm{BHI}$, cell population was estimated by measuring absorbance at $660 \mathrm{~nm}$ wavelength.

An adequate volume of juice was poured in autoclaved containers. The inoculation volume corresponded to an initial OD at $660 \mathrm{~nm}$ of 0.05 . For short-term cultures, a volume of $40 \mathrm{~mL}$ of inoculated juice was incubated in $250 \mathrm{~mL}$ Erlenmeyer flasks at $25^{\circ} \mathrm{C}$ in a shaking incubator at $150 \mathrm{rpm}$ for 48 h. Pasteurized juice was used as control. For each isolate and for both controls, the experiment was performed three times from independent pre-cultures.

\section{Identification}

DNA extraction was performed using Instagen protocol (Instagen Matrix, Biorad). The supernatant containing DNA was stored at $-20^{\circ} \mathrm{C}$.

Two primers (Eurogentec), RD1m 5'-GGM-TAC-CTT-ACG-AYT-TC-3' and FD1m 5'-AGA-GTT-TGA-TCHTGG-CTC-AG-3', were used for DNA amplification. The reaction mixture contained buffer $1 \mathrm{x}, \mathrm{dNTP} 2$ $\mathrm{mM}$, each primer $0.3 \mu \mathrm{M}, \mathrm{MgCl}_{2} 2.5 \mathrm{mM}$, and Taq polymerase $0.02 \mathrm{U} . \mu \mathrm{L}^{-1}$ (Diamond, Eurogentec). The PCR reaction was performed in a $45 \mu \mathrm{L}$-volume with $10 \mu \mathrm{L}$ of DNA solution. The PCR program comprised 35 cycles of denaturation for $40 \mathrm{~s}$ at $94^{\circ} \mathrm{C}$, annealing for $40 \mathrm{~s}$ at $55^{\circ} \mathrm{C}$ and elongation for 1 $\min$ at $72^{\circ} \mathrm{C}$. The cycles were preceded by a denaturation step at $94^{\circ} \mathrm{C}$ for 3 min and followed by an elongation step at $72^{\circ} \mathrm{C}$ for 10 min. PCR was performed with a Bio-Rad S100 Thermal Cycler. PCR products were separated by electrophoresis (60 min at $100 \mathrm{~V}$ ) on $0.8 \%$ agarose gel in TAE 0.5x. DNA was detected with a GelDoc UV-illuminator system (Bio-Rad) after staining with ethidium bromide. The $1 \mathrm{~kb}$ DNA ladder (Invitrogen) was used. PCR product purification was performed with GenElute PCR Clean-up Kit (Sigma-Aldrich). PCR product was sequenced by Sanger method with FD1m primer (Eurofins). The obtained sequence was 
compared to Ribosomal Database Project (Cole et al. 2014) and NCBI Nucleotide with BLASTN program. Alignments were performed with CLUSTAL OMEGA program (EMBL) (Sievers et al. 2011) and trees were built up with JalView (Waterhouse et al. 2009).

A rep-PCR method based on (GTG) 5 primer was used to differentiate species. Reference strains DSM2601 (Lb. plantarum), DSM 20174 (Lb. plantarum Type strain), DSM 20188 (Leuconostoc citreum), DSM 5625 (Leuconostoc pseudomesenteroides), DSM 20193 (Leuc. pseudomesenteroides Type strain), DSM 15830 (Weissella koreensis Type strain), DSM 20196 (Weissella confusa Type strain), DSM 5625 (Weissella cibaria), DSM 15878 (W. cibaria Type strain) were used as control. PCR was performed according to Versalovic et al. (1994) with some modifications. The PCR reaction was performed in $50 \mu \mathrm{L}$ containing $10 \mu \mathrm{L}$ of DNA solution. The reaction mixture contains $1 \mathrm{X}$ buffer, dNTP 2mM, (GTG) 5 primer 5'-GTG-GTG-GTG-GTG-GTG-3' $2 \mu \mathrm{M}$ (Eurogentec), $\mathrm{MgCl}_{2} 4 \mathrm{mM}$ and Taq polymerase 0.0375 U. $\mu L^{-1}$ (5 PRIME). The (GTG) ${ }_{5}$ PCR program comprised 30 cycles of denaturation for $1 \mathrm{~min}$ at $94^{\circ} \mathrm{C}$, annealing for $1 \mathrm{~min}$ at $40^{\circ} \mathrm{C}$ and elongation for $3 \mathrm{~min}$ at $72^{\circ} \mathrm{C}$. The cycles were preceded by a denaturation step at $94^{\circ} \mathrm{C}$ for $5 \mathrm{~min}$ and followed by an elongation step at $72^{\circ} \mathrm{C}$ for 10 min. PCR was performed with a Bio-Rad S100 Thermal Cycler. PCR products were separated by electrophoresis in a $0.8 \%$ agarose gel $(20 \times 20)$ for 6 hours at $80 \mathrm{~V}$ in $1 \times$ TAE. DNA was detected as previously described by comparison with $1 \mathrm{~kb}$ and $100 \mathrm{bp}$ DNA ladders (Nippon Genetics). Electrophoretic profiles were analyzed with Phoretix 1D Pro software (Totallab, UK). Nearest Neighbor algorithm and Pearson coefficient correlation were used to build the dendrogram.

\section{Exopolysaccharide (EPS) production}

Screening for EPS producing phenotype was carried out from colony aspect after growth at $30^{\circ} \mathrm{C}$ during $72 \mathrm{~h}$ on MRS medium supplemented with $40 \mathrm{~g} \cdot \mathrm{L}^{-1}$ of sucrose. The phenotype was rated according to mucoid appearance with attributes: (-) non mucoid/non EPS-producing; (+) EPSproducing; (++) high EPS producing and (+++) very high EPS producing. The colony aspect of EPS producing isolates was described as liquid or creamy.

\section{Acidification kinetics}


Bacterial isolates were reactivated for $48 \mathrm{~h}$ at $37^{\circ} \mathrm{C}$ in $\mathrm{BHI}$ broth. They were inoculated in $150 \mathrm{~mL}$ of $\mathrm{BHI}$ broth. Volume of inoculation was calculated corresponding to an initial OD at $660 \mathrm{~nm}$ of 0.05. Cultures were incubated at $25^{\circ} \mathrm{C}$ in a water bath under agitation at $100 \mathrm{rpm}$ with a magnetic stirrer. A pH probe connected to an automated acquisition system (Consor multi-parameter analyser C3060) was plunged in each culture. The medium $\mathrm{pH}$ values were acquired for $72 \mathrm{~h}$ with a time interval of 5 min with CINAC Software. Acidification curve was obtained by plotting $\mathrm{pH}$ as a function of time. Each culture was performed in duplicate. Lag time $\lambda$ was the time corresponding to an initial $\mathrm{pH}$ variation below 0.1. Minimal $\mathrm{pH} \mathrm{pH}_{\min }$ was the final constant $\mathrm{pH}$ value. Maximum acidification rate $\mathrm{V}_{\mathbf{M}}$, time to reach the maximum acidification rate without the lag phase $t_{M}$ and $\mathrm{pH}$ at maximal acidification rate $\mathrm{pH}_{\mathrm{M}}$ were determined from $\mathrm{dpH} / \mathrm{dt}=\mathrm{f}(\mathrm{t})$ curves obtained with Regressi Software.

\section{Adaptation}

Bacterial isolates were grown for $48 \mathrm{~h}$ at $37^{\circ} \mathrm{C}$ in $\mathrm{BHI}$ broth $\mathrm{pH} 6.8$ and $0.2 \mathrm{~mL}$ fraction of this bacterial suspension was inoculated into 9-mL assay broths. The control medium used was BHI broth $\mathrm{pH} 6.8$. For acid stress adaptation, $\mathrm{BHI}$ broth acidified to $\mathrm{pH} 4.5$ with $\mathrm{HCl} 2 \mathrm{M}$ was used. For osmotic stress adaptation, $\mathrm{BHI}$ broth containing $5 \% \mathrm{NaCl}$ was used. For oxidative stress, $\mathrm{BHI}$ broth containing 0.025 $\%$ or $0.05 \% \mathrm{H}_{2} \mathrm{O}_{2}$ or $0.07 \% \mathrm{H}_{2} \mathrm{O}_{2}$ was used. $\mathrm{OD}$ at $660 \mathrm{~nm}$ was measured just after inoculation $\left(\mathrm{OD}_{0}\right)$ and after incubation at $37^{\circ} \mathrm{C}$ for $48 \mathrm{~h}\left(O D_{48}\right)$. Results were expressed as $\log \left(O D_{48} / O D_{0}\right)$. All adaptation assays were performed in triplicate for each isolate.

\section{Analysis of pineapple juice}

All chemicals were purchased from Sigma Aldrich. Reducing sugar content was determined according to Miller method (Miller 1959). Cell counts were performed after inoculation and after $48 \mathrm{~h}$ of incubation by MRS platting. Seven different assays were used to evaluate the antioxidant activity. Each test was performed in independent triplicates for each sample and control.

\section{Oxygen Radical Absorbance Capacity (ORAC) analysis}

Oxygen Radical Absorbance Capacity (ORAC) analysis was used to determine antioxidant capacity of 5000-fold diluted, fermented or non-fermented, pineapple juices. The antioxidant activity of the 
sample was determined from its capacity to reduce fluorescein oxidation by peroxyl radicals generated with AAPH (2,2'-Azobis [2-methyl- propionamidin]dihydrochloride). Briefly, in a black 96well plate, $25 \mu \mathrm{L}$ of sample were mixed with $150 \mu \mathrm{L}$ of $0.0838 \mu \mathrm{M}$ fluorescein prepared in $1 \mathrm{M}$ phosphate buffer $\mathrm{pH}$ 7.4. After $15 \mathrm{~min}$ of incubation at $37^{\circ} \mathrm{C}$ in the TECAN INFINITE M200 spectrofluorimeter, $25 \mu \mathrm{L}$ of $153 \mathrm{mM}$ AAPH were added in each well. Decrease in fluorescence corresponding to fluorescein oxidation was measured at excitation and emission wavelengths of 485 and $530 \mathrm{~nm}$ respectively. Trolox at concentrations of 20,50 and $100 \mu \mathrm{M}$ was used as standard. The area under the curve (AUC) was determined automatically for each sample and for each Trolox concentration. Standard curve was established by plotting AUC versus Trolox concentration. Antioxidant activity was expressed as $\mu \mathrm{M}$ Trolox equivalent.

\section{Erythrocytes hemolysis}

In this assay, antioxidant activity of a sample corresponds to its capacity to inhibit erythrocyte oxidation by radicals generated from AAPH. Erythrocytes were separated from the plasma by centrifugation at $1000 \times g$ for $5 \mathrm{~min}$. The supernatant was removed and the same volume of $0.15 \mathrm{M}$ $\mathrm{NaCl}$ solution was added. This washing step was repeated three times. Afterwards, erythrocyte solution was reconstituted by adding a volume of $\mathrm{NaCl}$ solution equivalent to initial plasma volume. In a 96-well plate, $100 \mu \mathrm{L}$ of 50-fold diluted erythrocytes were mixed with 10,000 -fold diluted samples in $0.15 \mathrm{M} \mathrm{NaCl}$. Then, $40 \mu \mathrm{L}$ of $0.5 \mathrm{M} \mathrm{AAPH}$ solution was added in each well. The microplate was incubated at $37^{\circ} \mathrm{C}$ and hemolysis was followed by the decrease of absorbance at $450 \mathrm{~nm}$ (FLUOSTAR - BMG France). Omega-5 software was used to acquire absorbance values. Results are expressed in half time of hemolysis (HT50), determined from GraphPad Prism 2.01 with a Boltzman

sigmoidal nonlinear regression. The equation was: $\mathrm{Y}=\mathrm{Absi}+\frac{A b s f-A b s i}{1+\exp ^{\frac{V 50-x}{\operatorname{slope}}}}$ where $\mathrm{Y}$ is the absorbance at $450 \mathrm{~nm}$, Absi the initial absorbance at $450 \mathrm{~nm}$, Absf the final absorbance at $450 \mathrm{~nm}$, and V-50 the half time hemolysis, expressed in min, and slope is the steepness of the curve.

\section{OD 280nm measurement}


Pineapple juice fermented or not was diluted 10 -fold in ultrapure water, before the measurement of OD at $280 \mathrm{~nm}$. Gallic acid was used as standard. Results are expressed as g. $^{-1}$ gallic acid equivalent (GAE).

\section{Determination of total phenolic content}

The Folin-Ciocalteau method with gallic acid (GA) as standard was used and samples were 100 -fold diluted. In a 96-well plate, $15 \mu \mathrm{L}$ of Folin reagent was mixed with $30 \mu \mathrm{L}$ of each sample or standard. After incubation for $4 \mathrm{~min}$ at ambient temperature, $60 \mu \mathrm{L} \mathrm{of} \mathrm{Na}_{2} \mathrm{CO}_{3} 700 \mathrm{mM}$ was added to stop the reaction. Then $195 \mu \mathrm{L}$ of distilled water was added. After incubation for $1 \mathrm{~h}$ at room temperature, absorbance at $760 \mathrm{~nm}$ was measured. Results were expressed as $\mathrm{g} . \mathrm{L}^{-1}$ gallic acid equivalent (GAE). 2,2'-azinobis-(3-ethylbenzothiazoline-6-sulfonic acid) (ABTS) free radical scavenging activity ABTS is oxidized by potassium persulfate $\mathrm{K}_{2} \mathrm{~S}_{2} \mathrm{O}_{8}$ to generate cation radical $A B T S^{\circ+}$ which absorbs at $734 \mathrm{~nm}$. Antioxidant compounds degrade this radical, resulting in a decrease of absorbance at 734 $\mathrm{nm}$. To generate the cation radical ABTS ${ }^{\circ+}, 5 \mathrm{~mL}$ of a solution of $7 \mathrm{mM}$ ABTS was added to $5 \mathrm{~mL}$ of $2.45 \mathrm{mM}$ potassium persulfate. $\mathrm{ABTS}^{\circ+}$ solution was then diluted in methanol in order to obtain an absorbance of 0.7 at $734 \mathrm{~nm}$. Samples were 5 -fold diluted in ultrapure water. In a transparent 96well plate, $280 \mu \mathrm{L}$ of $\mathrm{ABTS}^{\circ+}$ was mixed with $20 \mu \mathrm{L}$ of sample. The blank was obtained with $20 \mu \mathrm{L}$ of ultrapure water. After $5 \mathrm{~min}$ of incubation at $30^{\circ} \mathrm{C}$ in the Tecan Infinite $\mathrm{M} 200$ spectrofluorimeter, absorbance at $734 \mathrm{~nm}$ was measured. Trolox at concentrations $50 \mu \mathrm{M}$ to $250 \mu \mathrm{M}$ was used as standard. The \% of inhibition was expressed for Trolox and for samples with the formula: \% of inhibition $=100-100 * \frac{\text { Abs sample }}{\text { Abs blank }}$.

The curve indicating \% of inhibition versus Trolox concentrations was used as standard curve. Antioxidant activity was expressed in $\mathrm{mM} \mathrm{TE}$.

\section{1,1-Diphenyl-2-picrylhydrazyl (DPPH) free radical scavenging activity}

Diphenyl-2-picrylhydrazyl (DPPH) assay was used to determine the free radical scavenging activity of fermented and non-fermented pineapple juice. In a 96-well plate, $150 \mu \mathrm{L}$ of DPPH solution $(0.2 \mathrm{mM}$ in methanol) was mixed with $50 \mu \mathrm{L}$ of 5-fold diluted sample. The mixture was then kept at room 
temperature for $30 \mathrm{~min}$ in the dark. The absorbance of the mixture was measured at $517 \mathrm{~nm}$ using microplate reader (Fluostar). Results were expressed as a \% of inhibition of sample versus control. Trolox was used as positive control.

\section{Low-density lipoprotein (LDL) oxidation}

LDL (1.019 -1.055 g. mL $\left.{ }^{-1}\right)$ were isolated by sequential ultracentrifugation of pooled plasma from normolipidemic subjects (Beckman centrifuge). After dialysis against PBS pH 7.4, LDL

were assayed for protein content by the bicinchoninic acid method and stored at $4^{\circ} \mathrm{C}$ in the dark for no longer than 15 days.

LDL oxidation was determined by measuring conjugated diene formation. Oxidation of LDL was conducted with $50 \mu \mathrm{L}$ of $1.96 \mu \mathrm{g} \cdot \mu^{-1}$ of LDL protein in the presence of $30 \mu \mathrm{L}$ samples $(10,000-$ fold dilution). Negative control consisted of $30 \mu \mathrm{L}$ of distilled water. Reaction was started by adding $20 \mu \mathrm{L}$ of $\mathrm{CuSO}_{4}$ solution $(80 \mu \mathrm{M})$. Conjugated diene absorbance was measured by spectrophotometry at $234 \mathrm{~nm}$ every $5 \mathrm{~min}$ during $2 \mathrm{~h}$ at $37^{\circ} \mathrm{C}$ by using a microplate reader (Fluostar). Results are expressed in half time oxidation (V-50), obtained from GraphPad Prism 2.01 with a Boltzman sigmoidal nonlinear regression, as for erythrocyte hemolysis assay. V-50 corresponds to the half time oxidation, expressed in $\min$.

\section{Statistics}

All values are expressed as mean \pm standard deviation.

Variance analysis and Student t-test have been used to compare the different treatments. If a significant difference was pointed out, Bonferroni test was used to test the difference between each treatment and control. Principal component analysis was performed with Pearson(n) matrix. The statistical analysis was performed using GraphPad Prism 2.01 (GraphPad Software, Inc) or XLSTAT (Addinsoft). Degrees of significance are indicated as follow: ${ }^{*} \mathrm{p}<0.05,{ }^{* *} \mathrm{p}<0.01,{ }^{* * *} \mathrm{p}<$ 0.001, ns $=$ not significant. 


\section{RESULTS}

\section{Isolation and molecular identification}

LAB population was determined from the different samples of papaya, tomato and sliced cabbage, purchased from local markets (Table1). The surface of the two fruits was characterized by LAB population comprised between 5.1 and $5.8 \log _{10} \mathrm{cfu} . \mathrm{g}^{-1}$, while sliced cabbage contained higher LAB population with 9.2 to $10.0 \log _{10} \mathrm{cfu}^{-1}$. Isolates were recovered from these samples on the basis of colony morphological differences and microscopy differences. Out of 64 LAB isolates, 10 isolates from six samples were chosen based on morphological differences and identified by $16 S$ rRNA coding region partial sequencing (Table 1). They belong to three different genera. Leuconostoc spp. was the most frequent. Isolates from papaya covered the three genera.

In order to distinguish species with highly identical 16S rRNA genomic sequences, a rep-PCR was applied. Similar profiles were obtained for isolates S9 and S13, S17 and S29, S5 and S6 and S12 and S27 respectively. Their comparison to reference strain profiles increased the accuracy of species assignment (Table 1 and Figure S1).

\section{EPS producing isolates}

Three isolates exhibited a negative EPS producing phenotype: S17, S29 and DSM2601. The isolates S5, S6, S9 and S10 resulted in high (+++) creamy colony phenotypes. The isolates S12 and S27 resulted in poor (+) liquid colony phenotypes. The isolates S13 and S14 did not succeed to grow under the test conditions.

\section{Acidification kinetics}

The 10 isolates were grown in $\mathrm{BHI}$, a nutrient-rich broth, for $72 \mathrm{~h}$ and $\mathrm{pH}$ was monitored every $5 \mathrm{~min}$. Two profiles of acidification were observed by plotting $\mathrm{dpH} / \mathrm{dt}$ as a function of time (Figure 1 ). $W$. cibaria and Lactobacillus spp. isolates exhibited a single acidification peak whereas Leuconostoc spp. isolates showed two peaks of acidification. From those profiles, several parameters were extracted: lag time, time for the first acidification peak $\left(t_{M}\right)$, maximal acidification rate $\left(V_{M}\right), p H$ at maximal rate $\left(\mathrm{pH}_{\mathrm{M}}\right)$ and minimal $\mathrm{pH}$ observed during the culture (Table 2). These parameters were used as 
variables for a principal component analysis, with isolates as observations (Figure 2). The two

projection axes, F1 and F2, were representative of variables and accounted for $83.71 \%$. Interestingly, the isolates grouped according to their genus. Leuconostoc spp. exhibited a long lag phase, a low $V_{M}$ and a high minimal $\mathrm{pH}$. Both $W$. cibaria and Lactobacillus spp. exhibited a short lag phase and a low minimal $\mathrm{pH}$, but $W$. cibaria showed a high $\mathrm{V}_{\mathrm{M}}$ contrarily to Lactobacillus spp.

One or two isolates of each genus were grown under the same conditions, but in MRS broth (Table 2). In this medium, the double peak profile was not observed for Leuconostoc spp. isolate. In MRS broth, maximal acidification rates were 2.4 to 4.5 fold higher than in $\mathrm{BHI}$ and minimal $\mathrm{pH}, \mathrm{pH}_{\mathrm{M}}$ and lag time were lower. Except for lag time, these parameters followed the same tendencies between isolates in $\mathrm{BHI}$ and in MRS broth.

\section{Growth and adaptation to sub-lethal stress}

An assay to evaluate isolate adaptation to different stress was standardized. The control condition showed that two isolates, S9 and S13, both Leuconostoc citreum, exhibited a poor growth in BHI over $48 \mathrm{~h}$ at $30^{\circ} \mathrm{C}$, with an OD variation of less than 0.2 (Figure 3a). For other isolates, $48 \mathrm{~h}$ OD variation without stress was comprised between 0.4 and 0.9 .

For these eight isolates, the stress adaptation assay was applied to evaluate adaptation to low $\mathrm{pH}$, to high sodium chloride level or to oxidative stress, in respect to control condition (Figure 3b, c).

Oxidative stress adaptation was tested with two concentrations of hydrogen peroxide, $0.025 \%$ and $0.05 \%$ (Figure 3b). The lowest $\mathrm{H}_{2} \mathrm{O}_{2}$ level resulted for $\mathrm{S} 12$ and $\mathrm{S} 27$, both $W$. cibaria isolates, in a $40 \%$ decrease of 48h-growth compared to non-stressing condition, whereas other isolates growth did not significantly decrease. The effect of $0.05 \% \mathrm{H}_{2} \mathrm{O}_{2}$ level was much more marked: growth of all isolates was affected but in different proportion. For instance, the effect of $0.05 \% \mathrm{H}_{2} \mathrm{O}_{2}$ was more pronounced on the growth of S12 and DSM2601 (p-value<0.001) whereas the effect on S14 was not significant. A level of $0.07 \% \mathrm{H}_{2} \mathrm{O}_{2}$ was tested, and none of the isolates was able to adapt to this concentration. Two isolates, S5 and S6, which belong to Leuc. mesenteroides, were particularly sensitive to $\mathrm{pH}$, whereas S17 and S29, identified as Lb. paraplantarum/pentosus were the most 
tolerant (Figure 3c). For W. cibaria, isolate S12, contrarily to isolate S27, was not able to grow in the presence of $5 \% \mathrm{NaCl}$ (Figure 3c). The highest salt tolerance was observed for S5 (Leuc.

mesenteroides), S10 and S14 (Leuc. pseudomesenteroides), DSM2601 and S27 (W. cibaria).

From the obtained data, four isolates demonstrated the best ability to adapt tested stress

individually: S10 and S14 (Leuc. pseudomesenteroides), S17 (Lactobacillus paraplantarum/pentosus) and S27 (W. cibaria).

\section{Pineapple antioxidant capacity modulation}

Each isolate was inoculated into pasteurized pineapple juice and incubated for $48 \mathrm{~h}$ at $25^{\circ} \mathrm{C}$ with agitation. Pineapple juice exhibited an initial $\mathrm{pH}$ of 3.6 and an initial reducing sugar level of $94.4 \pm$ 10.0 g.L ${ }^{-1}$. After 48h, no significant decrease in $\mathrm{pH}$ was observed and a significant growth was observed only for isolates S5, S12 and S17.

Antioxidant capacity was evaluated from seven different assays: ORAC, ABTS, hemolysis test, OD280nm measurement, DPPH, Folin-Ciocalteau, and LDL oxidation. Pasteurized juice was used as control.

From ORAC, ABTS, erythrocyte hemolysis, DPPH and OD 280nm assays, no significant difference could be observed between samples fermented with different isolates, neither between fermented juices versus control condition. The ORAC value for pineapple juice was $187 \pm 11 \mathrm{mM}$ TE. For ABTS assay, pineapple juice value was $57.0 \pm 3.2 \mathrm{mM}$ TE. Hemolysis test showed a HT50 (time for halfhemolysis) value of $103 \pm 49$ min for 100 -fold diluted juice, and DPPH assay resulted in a value of

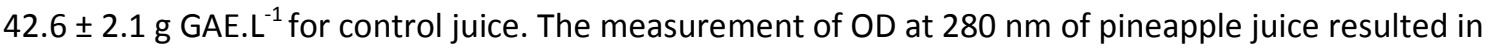
$300 \pm 18 \mathrm{~g} \mathrm{GAE} \cdot \mathrm{L}^{-1}$

Contrary to the above, Folin-Ciocalteau and LDL oxidation assays showed a number of variations (Figure 4).

Folin-Ciocalteau assay resulted in $1.15 \pm 0.05 \mathrm{~g} \mathrm{GAE} . \mathrm{L}^{-1}$ for pineapple juice. Pineapple juice fermented with isolate S14 (Leuc. pseudomesenteroides) exhibited a Folin-Ciocalteau value of $1.43 \pm 0.25 \mathrm{~g}$ 
GAE. $L^{-1}$. The two values significantly differed with a $p$-value of 0.06 . Other fermented juices did not differ from the control.

From LDL oxidation assay, the determination of V50, the time for half-LDL oxidation, was used to compare samples and control. Distilled water was used as control and showed a V50 value of $56.6 \pm$ $0.8 \mathrm{~min}$. A $10^{4}$-fold diluted juice did not exhibit a significant difference compared to water, but the use of $10^{3}$-fold diluted juice resulted in an absence of measurable oxidation of LDL by copper. Only the juice fermented with S27 (W. cibaria) and $10^{4}$-fold diluted exhibited a significant delayed oxidation versus control with a V50 value of $59.7 \pm 1.6 \mathrm{~min}$. The other diluted fermented juice did not differ from the control.

\section{DISCUSSION}

The interest in fruit or vegetable foods, and particularly in lactic fermented foods, has considerably increased over the last decade as these foods can significantly contribute to a healthy diet. In the present study, lactic acid bacteria were isolated from papaya, tomato or sliced cabbage samples, identified by molecular method and characterized for phenotypic traits related to technological properties relevant for food fermentation. A special focus was made on antioxidant activity, choosing an acidic fruit juice and a short incubation time for testing.

The sampled fruits and vegetables exhibited very diverse levels of $L A B$, with population ranging between 5.1 and $10.0 \mathrm{cfu} . \mathrm{g}^{-1}$. The highest population was observed for sliced cabbage, a ready-to-eat vegetable, for which cutting resulted in increased surface and nutrient availability. We limited our study to 10 isolates chosen from morphological diversity criterion, and those isolates were showed to belong to five different species and three genera. Whereas Weissella spp. and Leuconostoc spp. are frequently isolated from fermented foods, starters used in vegetable food fermentation essentially belong to Lactobacillus spp. Interestingly, isolates exhibited very different fermentation kinetics parameters. The use of acidification kinetics as a tool to monitor fermentation performance has been developed more than 25 years ago (Spinnler and Corrieu 1989) and has been widely applied to 
characterize dairy starters (Cachon et al. 2002; Latrille et al. 1992; Pinheiro De Souza Oliveira et al. 2009; Xanthopoulos et al. 2001). However, this tool has never been previously used to characterize Leuconostoc spp. or Weissella spp. Our study revealed that Weissella cibaria can act as a potent acidifier. No significant decrease of $\mathrm{pH}$ was observed during short-term fermentation of pineapple juice, probably as a consequence of the low initial $\mathrm{pH}$ (3.6). Dairy bacteria grown in milk exhibited $\mathrm{V}_{\mathrm{M}}$ values that range between 0.2 and $1.2 \mathrm{UpH} . \mathrm{h}^{-1}$ and $\mathrm{T}_{\mathrm{M}}$ between 3 and $10 \mathrm{~h}$ (Cachon et al. 2002; Latrille et al. 1992; Pinheiro De Souza Oliveira et al. 2009; Xanthopoulos et al. 2001). In our study, the values of $\mathrm{V}_{\mathrm{M}}$ on MRS broth ranged between 0.10 and $0.15 \mathrm{UpH} . \mathrm{h}^{-1}$ whatever the species, which is by far much lower than $V_{M}$ observed in dairy studies. MRS broth is recommended for LAB culture: as expected, even lower $\mathrm{V}_{\mathrm{M}}$ were observed in BHI. Interestingly, acidification kinetics in BHI showed genus related patterns, hereby characterized by $\mathrm{V}_{\mathrm{M}}, \mathrm{t}_{\mathrm{M}}, \mathrm{pH}_{\mathrm{M}}$, minimal $\mathrm{pH}$ and lag time. Differences between slow and rapid fermentative isolates and between high and low acidifiers were easily pointed out in this medium.

The comparison of growth yield between un-stressing and stressing conditions is critical since fermentation generally results from bacterial competition in a stressing environment (Serrazanetti et al. 2013). Indeed, most fruits and many vegetables exhibit a low pH. Moreover, addition of salt in vegetable preparations is often used as a selective agent. Stress adaptation ability widely differed between isolates, even within the same species. Interestingly, S12 and S27, both W. cibaria, shared similar (GTG) 5 profile, but showed different stress adaptation ability. On the contrary, S17 and S29, both $L$ b. paraplantarum/pentosus, shared similar $(\mathrm{GTG})_{5}$ profile and showed same adaptation patterns. Several mechanisms are involved in LAB stress tolerance: glutathione system (Kim et al. 2012; Zhang and Li 2013), the so-called general stress response or acid tolerance response (ATR) (van de Guchte et al. 2002), and the ability to detoxify reactive oxygen species, thanks to antioxidant enzymes (An et al. 2011; Bruno-Bárcena et al. 2010; Ramesh et al. 2011). Although LAB are catalase negative, other enzymes, such as superoxide dismutase, peroxidases or NADH oxidases might be 
involved in detoxification. These key-activities deserve to be determined in the most resistant isolates.

Recently, a relationship between redox regulation mechanisms and production of exopolysaccharides (EPS) was shown in Lactobacillus casei (Zhang and Li 2013). Moreover, many EPS, produced by Leuconostoc spp., were shown to exhibit antioxidant activities by themselves (Li et al. 2014; Pan and Mei 2010). As Weissella spp. is a high EPS producer, investigation of the activities of enzymes involved in intracellular redox balance and oxidative stress detoxification is of particular importance for this genus.

The contribution of a short fermentation time to the antioxidant capacity of pineapple juice was poor. Only two antioxidant capacity tests, Folin-Ciocalteau and LDL oxidation assays, showed significant differences between fermented juice and control. Noteworthy enough, this fermentation step did not result in a loss of antioxidant capacity of juice. Other studies have pointed differences in antioxidant capacity after fermentation. For instance, in olives, in green or red smoothies or in pomegranate juice, fermentation with $L b$. plantarum, alone or associated with $W$. cibaria or Pediococcus pentosaceus, decreased the antioxidant capacity (Di Cagno et al. 2011; Filannino et al. 2013; Othman et al. 2009). In other studies, over a very short time (8-17h) of fermentation of tempeh (soybean seeds) or tomato juice with $L b$. plantarum, the antioxidant capacity was maintained (Di Cagno et al. 2009; Starzyńska-Janiszewska et al. 2014). Conversely, fermentation of white cabbage over 7 days, with Lb. plantarum and/or Leuc. mesenteroides, showed a two-fold increase in the antioxidant capacity measured with ORAC (Martinez-Villaluenga et al. 2012). Similarly, the antioxidant activity of soymilk increased by three-fold after $24 \mathrm{~h}$ fermentation with a $L b$. rhamnosus starter (Marazza et al. 2012). The relationship between antioxidant capacity modulation and changes in composition or enzyme activities deserve to be extensively investigated. Based on stress tolerance, four isolates appeared resistant: S10, S14, S17 and S27. They were distributed over the four species identified. All four isolates revealed very different acidification kinetics. Among those, only S14 and S27 modulated significantly the juice antioxidant capacity. The 
applied method is thus relevant to identify potential starters which may be used to perform mild or strong, slow or rapid food fermentation. A larger screening of isolates, completed with enzymatic activity screening, could highlight relationships between stress resistance, ability to modulate antioxidant capacity and enzyme activities.

Isolate S14 belong to Leuc. pseudomesenteroides species and isolate S27 to W. cibaria. These species are commonly identified from fermented vegetables, including cabbage and olive (Di Cagno et al. 2013). However, their use as starters is not yet described. In addition, the physiological properties of Weissella spp. are still poorly known, but recently niche specific features were highlighted at genomic level (Lynch et al. 2015). The S27 isolate showed in this study a high potential for its use as starter for fermented fruit or vegetable juices. An experimental plan with different fruit juices and different fermentation durations is warranted in order to determine the safety and the sensorial properties of the resulting food.

\section{ACKNOWLEDGEMENTS}

This study was supported by grants from the structure Fédérative Environnement, Biodiversité et Santé, University of La Reunion. AF PhD is supported by a fellowship from the "Conseil Regional de La Réunion et l'Europe". We thank Pr Teeshan Bahorun, Centre of Excellence for Biomedical and Biomaterials Research, University of Mauricius, for careful reading.

\section{REFERENCES}

An, H., Zhai, Z., Yin, S., Luo, Y., Han, B., Hao, Y., 2011. Coexpression of the superoxide dismutase and the catalase provides remarkable oxidative stress resistance in Lactobacillus rhamnosus. J. Agric.

Food Chem. 59, 3851-6. doi:10.1021/jf200251k

Bourdichon, F., Casaregola, S., Farrokh, C., Frisvad, J.C., Gerds, M.L., Hammes, W.P., Harnett, J., Huys, G., Laulund, S., Ouwehand, A., Powell, I.B., Prajapati, J.B., Seto, Y., Ter Schure, E., Van Boven, A., 
Vankerckhoven, V., Zgoda, A., Tuijtelaars, S., Hansen, E.B., 2012. Food fermentations:

microorganisms with technological beneficial use. Int. J. Food Microbiol. 154, 87-97.

doi:10.1016/j.ijfoodmicro.2011.12.030

Bruno-Bárcena, J.M., Azcárate-Peril, M.A., Hassan, H.M., 2010. Role of antioxidant enzymes in bacterial resistance to organic acids. Appl. Environ. Microbiol. 76, 2747-53. doi:10.1128/AEM.0271809

Cachon, R., Jeanson, S., Adarf, M., Divies, C., 2002. Characterization of lactic starters based on acidification and reduction activities. Lait $\mathbf{8 2}$, 281-288.

Cole, J.R., Wang, Q., Fish, J.A., Chai, B., McGarrell, D.M., Sun, Y., Brown, C.T., Porras-Alfaro, A., Kuske, C.R., Tiedje, J.M., 2014. Ribosomal Database Project: data and tools for high throughput rRNA analysis. Nucleic Acids Res. 42, D633-42. doi:10.1093/nar/gkt1244

Di Cagno, R., Coda, R., De Angelis, M., Gobbetti, M., 2013. Exploitation of vegetables and fruits through lactic acid fermentation. Food Microbiol. 33, 1-10. doi:10.1016/j.fm.2012.09.003

Di Cagno, R., Minervini, G., Rizzello, C.G., De Angelis, M., Gobbetti, M., 2011. Effect of lactic acid fermentation on antioxidant, texture, color and sensory properties of red and green smoothies. Food Microbiol. 28, 1062-71. doi:10.1016/j.fm.2011.02.011

Di Cagno, R., Surico, R.F., Paradiso, A., De Angelis, M., Salmon, J.-C., Buchin, S., De Gara, L., Gobbetti, M., 2009. Effect of autochthonous lactic acid bacteria starters on health-promoting and sensory properties of tomato juices. Int. J. Food Microbiol. 128, 473-83.

doi:10.1016/j.ijfoodmicro.2008.10.017

Filannino, P., Azzi, L., Cavoski, I., Vincentini, O., Rizzello, C.G., Gobbetti, M., Di Cagno, R., 2013. Exploitation of the health-promoting and sensory properties of organic pomegranate (Punica 
granatum L.) juice through lactic acid fermentation. Int. J. Food Microbiol. 163, 184-92.

doi:10.1016/j.ijfoodmicro.2013.03.002

Franz, C.M.A.P., Huch, M., Mathara, J.M., Abriouel, H., Benomar, N., Reid, G., Galvez, A., Holzapfel, W.H., 2014. African Fermented Foods and Probiotics. Int. J. Food Microbiol. 190, 84-96. doi:10.1016/j.ijfoodmicro.2014.08.033

Giraffa, G., 2004. Studying the dynamics of microbial populations during food fermentation. FEMS Microbiol. Rev. 28, 251-60. doi:10.1016/j.femsre.2003.10.005

Hugenholtz, J., 2013. Traditional biotechnology for new foods and beverages. Curr. Opin. Biotechnol. 24, 155-9. doi:10.1016/j.copbio.2013.01.001

Juodeikiene, G., Bartkiene, E., Viskelis, P., Urbonaviciene, D., Eidukonyte, D., Bobinas, C., 2012. Fermentation processes using lactic acid bacteria producing bacteriocins for preservation and improving functional properties of food products, Advances in Applied Biotechnology. InTech, Rijeka, Croatia.

Kim, J.E., Eom, H.-J., Kim, Y., Ahn, J.E., Kim, J.H., Han, N.S., 2012. Enhancing acid tolerance of Leuconostoc mesenteroides with glutathione. Biotechnol. Lett. 34, 683-7. doi:10.1007/s10529-0110815-1

Lan, C.-H., Son, C.-K., Ha, H.P., Florence, H., Binh, L.T., Mai, L.-T., Tram, N.T.H., Khanh, T.T.M., Phu, T.V., Dominique, V., Yves, W., 2013. Tropical traditional fermented food, a field full of promise. Examples from the Tropical Bioresources and Biotechnology programme and other related FrenchVietnamese programmes on fermented food. Int. J. Food Sci. Technol. 48, 1115-1126. doi:10.1111/ijfs.12064 
Latrille, E., Picque, D., Perret, B., Corrieu, G., 1992. Characterizing acidification kinetics by measuring $\mathrm{pH}$ and electrical conductivity in batch thermophilic lactic fermentations. J. Ferment. Bioeng. 74, 3238. doi:10.1016/0922-338X(92)90264-U

Li, W., Ji, J., Chen, X., Jiang, M., Rui, X., Dong, M., 2014. Structural elucidation and antioxidant activities of exopolysaccharides from Lactobacillus helveticus MB2-1. Carbohydr. Polym. 102, 351-9. doi:10.1016/j.carbpol.2013.11.053

Liu, S., Han, Y., Zhou, Z., 2011. Lactic acid bacteria in traditional fermented Chinese foods. Food Res. Int. 44, 643-651. doi:10.1016/j.foodres.2010.12.034

Lynch, K.M., Lucid, A., Arendt, E.K., Sleator, R.D., Lucey, B., Coffey, A., 2015. Genomics of Weissella cibaria with an examination of its metabolic traits. Microbiology 161, 914-30.

doi:10.1099/mic.0.000053

Marazza, J. a., Nazareno, M. a., de Giori, G.S., Garro, M.S., 2012. Enhancement of the antioxidant capacity of soymilk by fermentation with Lactobacillus rhamnosus. J. Funct. Foods 4, 594-601. doi:10.1016/j.jff.2012.03.005

Martinez-Villaluenga, C., Peñas, E., Sidro, B., Ullate, M., Frias, J., Vidal-Valverde, C., 2012. White cabbage fermentation improves ascorbigen content, antioxidant and nitric oxide production inhibitory activity in LPS-induced macrophages. LWT - Food Sci. Technol. 46, 77-83. doi:10.1016/j.Iwt.2011.10.023

Miller, G.L., 1959. Use of dinitrosalicylic acid reagent for determination of reducing sugar. Anal. Chem. 31, 426-428. doi:10.1021/ac60147a030 
Ng, C.-C., Wang, C.-Y., Wang, Y.-P., Tzeng, W.-S., Shyu, Y.-T., 2011. Lactic acid bacterial fermentation on the production of functional antioxidant herbal Anoectochilus formosanus Hayata. J. Biosci.

Bioeng. 111, 289-93. doi:10.1016/j.jbiosc.2010.11.011

Nguyen, D.T.L., Van Hoorde, K., Cnockaert, M., De Brandt, E., Aerts, M., Binh Thanh, L., Vandamme, P., 2013. A description of the lactic acid bacteria microbiota associated with the production of traditional fermented vegetables in Vietnam. Int. J. Food Microbiol. 163, 19-27. doi:10.1016/j.ijfoodmicro.2013.01.024

Noumo, T.N., Tatsadjieu, L.N., Montet, D., Moses, F.M.C., 2013. Effect of pure culture fermentation on biochemical composition of Moringa oleifera lam leaves powders. Food Nutr. Sci. 04, 851-859. doi:10.4236/fns.2013.48111

Oguntoyinbo, F.A., Sanni, A.I., Franz, C.M.A.P., Holzapfel, W.H., 2007. In vitro fermentation studies for selection and evaluation of Bacillus strains as starter cultures for the production of okpehe, a traditional African fermented condiment. Int. J. Food Microbiol. 113, 208-18. doi:10.1016/j.ijfoodmicro.2006.07.006

Othman, N. Ben, Roblain, D., Chammen, N., Thonart, P., Hamdi, M., 2009. Antioxidant phenolic compounds loss during the fermentation of Chétoui olives. Food Chem. 116, 662-669. doi:10.1016/j.foodchem.2009.02.084

Pan, D., Mei, X., 2010. Antioxidant activity of an exopolysaccharide purified from Lactococcus lactis subsp. lactis 12. Carbohydr. Polym. 80, 908-914. doi:10.1016/j.carbpol.2010.01.005

Park, J.-M., Shin, J.-H., Gu, J.-G., Yoon, S.-J., Song, J.-C., Jeon, W.-M., Suh, H.-J., Chang, U.-J., Yang, C.Y., Kim, J.-M., 2011. Effect of antioxidant activity in kimchi during a short-term and over-ripening fermentation period. J. Biosci. Bioeng. 112, 356-9. doi:10.1016/j.jbiosc.2011.06.003 
Pinheiro De Souza Oliveira, R., Perego, P., Converti, A., De Oliveira, M.N., 2009. Effect of inulin on growth and acidification performance of different probiotic bacteria in co-cultures and mixed culture with Streptococcus thermophilus. J. Food Eng. 91, 133-139. doi:10.1016/j.jfoodeng.2008.08.013

Ramesh, V., Kumar, R., Singh, R.R.B., Kaushik, J.K., Mann, B., 2011. Comparative evaluation of selected strains of lactobacilli for the development of antioxidant activity in milk. Dairy Sci. Technol.

92, 179-188. doi:10.1007/s13594-011-0048-z

Rodriguez, H., Curiel, J.A., Landete, J.M., de las Rivas, B., Lopez de Felipe, F., Gomez-Cordoves, C., Mancheno, J.M., Munoz, R., 2009. Food phenolics and lactic acid bacteria. Int. J. Food Microbiol. 132, 79-90. doi:10.1016/j.ijfoodmicro.2009.03.025

Serrazanetti, D., Gottardi, D., Montanari, C., Gianotti, A., 2013. Dynamic stresses of lactic acid bacteria associated to fermentation processes, in: Intech Open Science (Ed.), Lactic Acid Bacteria - R \& D for Food, Health and Livestock Purposes. p. chapter 23.

Sievers, F., Wilm, A., Dineen, D., Gibson, T.J., Karplus, K., Li, W., Lopez, R., McWilliam, H., Remmert, M., Söding, J., Thompson, J.D., Higgins, D.G., 2011. Fast, scalable generation of high-quality protein multiple sequence alignments using Clustal Omega. Mol. Syst. Biol. 7, 539. doi:10.1038/msb.2011.75

Spinnler, H.E., Corrieu, G., 1989. Automatic method to quantify starter activity based on pH measurement. J. Dairy Res. 56, 755-764.

Starzyńska-Janiszewska, A., Stodolak, B., Mickowska, B., 2014. Effect of controlled lactic acid fermentation on selected bioactive and nutritional parameters of tempeh obtained from unhulled common bean (Phaseolus vulgaris) seeds. J. Sci. Food Agric. 94, 359-66. doi:10.1002/jsfa.6385

Sun, Y.-P.P., Chou, C.-C.C., Yu, R.-C.C., 2009. Antioxidant activity of lactic-fermented Chinese cabbage. Food Chem. 115, 912-917. doi:10.1016/j.foodchem.2008.12.097 
Van de Guchte, M., Serror, P., Chervaux, C., Smokvina, T., Ehrlich, S.D., Maguin, E., 2002. Stress responses in lactic acid bacteria. Antonie Van Leeuwenhoek 82, 187-216.

doi:10.1023/A:1020631532202

Versalovic, J., Schneider, M., De Bruijn, F.J., Lupski, J.R., 1994. Genomic fingerprinting of bacteria using repetitive sequence-based polymerase chain reaction. Methods Mol. Cell. Biol. $\mathbf{5}$.

Waterhouse, A.M., Procter, J.B., Martin, D.M.A., Clamp, M., Barton, G.J., 2009. Jalview Version 2--a multiple sequence alignment editor and analysis workbench. Bioinformatics 25, 1189-91. doi:10.1093/bioinformatics/btp033

Wu, S.-C., Su, Y.-S., Cheng, H.-Y., 2011. Antioxidant properties of Lactobacillus-fermented and nonfermented Graptopetalum paraguayense E. Walther at different stages of maturity. Food Chem. 129, 804-809. doi:10.1016/j.foodchem.2011.05.025

Xanthopoulos, V., Petridis, D., Tzanetakis, N., 2001. Characterization and classification of Streptococcus thermophilus and Lactobacillus delbrueckii subsp. bulgaricus strains isolated from traditional Greek yogurts. J. Food Sci. 66, 747-752. doi:10.1111/j.1365-2621.2001.tb04632.x

Zhang, Y., Li, Y., 2013. Engineering the antioxidative properties of lactic acid bacteria for improving its robustness. Curr. Opin. Biotechnol. 24, 142-7. doi:10.1016/j.copbio.2012.08.013 
TABLES 
Table 1: Origin and identification of isolates

\begin{tabular}{|c|c|c|c|c|c|c|}
\hline Isolate & Origin & $\begin{array}{l}\text { Numeration } \\
\left(\text { cfu.g } \text { - }^{-1}\right)\end{array}$ & $\begin{array}{l}\text { 16S partial } \\
\text { sequence (bp) }\end{array}$ & \% ID & Species & (GTG)5 profile \\
\hline S5 & Papaya & $1.3310^{5}$ & 430 & 99\% LN774434.1 & Leuc. mesenteroides/pseudomesenteroides & $\begin{array}{l}\text { Leuc. } \\
\text { mesenteroides }\end{array}$ \\
\hline S6 & Papaya & $1.3310^{5}$ & 939 & $99 \% \mathrm{KJ} 477421.1$ & Leuc. mesenteroides/pseudomesenteroides & $\begin{array}{l}\text { Leuc. } \\
\text { mesenteroides }\end{array}$ \\
\hline S9 & Papaya & $1.3310^{5}$ & 941 & 99\% AB904775.1; HF562952.1 & Leuc. holzapfelii/citreum & Leuc. citreum \\
\hline S10 & Papaya & $1.3310^{5}$ & 945 & 99\% GQ351323.1 & Leuc. mesenteroides/pseudomesenteroides & ND* \\
\hline S13 & Tomato & $6.6410^{5}$ & 915 & 99\% KF879147.1; АB904775.1 & Leuc. holzapfelii/citreum & Leuc. citreum \\
\hline S14 & $\begin{array}{l}\text { Sliced } \\
\text { cabbage }\end{array}$ & $1.5710^{9}$ & 921 & $99 \%$ KF879168.1 & Leuc. mesenteroides/pseudomesenteroides & ND \\
\hline S12 & Papaya & $1.3310^{5}$ & 935 & $99 \%$ AB761300.1 & W. cibaria/confusa & W. cibaria \\
\hline S27 & $\begin{array}{l}\text { Sliced } \\
\text { cabbage }\end{array}$ & $1.0710^{10}$ & 879 & $100 \%$ HF562959 & W. cibaria/confusa & W. cibaria \\
\hline S17 & Papaya & $1.3010^{5}$ & 879 & 99\% KJ690749.1; KJ690750.1 & Lb. plantarum/paraplantarum/pentosus & $\begin{array}{l}\text { Lb. paraplantarum } \\
\text { /pentosus }\end{array}$ \\
\hline S29 & Tomato & $6.6410^{5}$ & 614 & $\begin{array}{l}\text { 99\% KC } 914585.1 \\
\text { KP189214.1 }\end{array}$ & Lb. plantarum/paraplantarum/pentosus & $\begin{array}{l}\text { Lb. paraplantarum } \\
\text { /pentosus }\end{array}$ \\
\hline $\begin{array}{l}\text { DSM } \\
2601\end{array}$ & $\begin{array}{l}\text { Pickled } \\
\text { cabbage }\end{array}$ & - & & & Lb. plantarum & \\
\hline
\end{tabular}

* ND: not determined 
Table 2: Parameters of acidification (mean \pm standard deviation)

\begin{tabular}{|c|c|c|c|c|c|c|c|c|c|c|c|c|c|c|c|}
\hline Isolate & \multicolumn{3}{|c|}{ Lag time $(\mathrm{h})$} & \multicolumn{3}{|c|}{$\mathrm{pH} \min$} & \multicolumn{3}{|c|}{$\mathrm{V}_{\mathrm{M}}\left(\mathrm{mU} \mathrm{pH} \cdot \mathrm{h}^{-1}\right)$} & \multicolumn{3}{|c|}{$\mathrm{pH}_{\mathrm{M}}$} & \multicolumn{3}{|c|}{$t_{M}(h)$} \\
\hline \multicolumn{16}{|c|}{ Growth in BHI (initial pH 6.8) } \\
\hline S5 & 11.42 & \pm & 3.42 & 5.9 & \pm & 0.1 & 32 & \pm & 1 & 6.3 & \pm & 0.2 & 4.29 & \pm & 0.41 \\
\hline S9 & 5.13 & \pm & 0.77 & 5.9 & \pm & 0.1 & 38 & \pm & 5 & 6.4 & \pm & 0.1 & 4.00 & \pm & 0.59 \\
\hline S10 & 4.17 & \pm & 0.59 & 6.2 & \pm & 0.2 & 38 & \pm & 7 & 6.4 & \pm & 0.1 & 3.00 & \pm & 0.47 \\
\hline S12 & 6.58 & \pm & 2.24 & 4.9 & \pm & 0.1 & 66 & \pm & 3 & 6.1 & \pm & 0.1 & 5.13 & \pm & 0.12 \\
\hline S27 & 2.04 & \pm & 1.24 & 4.9 & \pm & 0.1 & 50 & \pm & 1 & 6.1 & \pm & 0.6 & 6.25 & \pm & 1.36 \\
\hline S17 & 10.96 & \pm & 0.06 & 5.6 & \pm & 0.1 & 43 & \pm & 1 & 6.2 & \pm & 0.1 & 11.29 & \pm & 0.35 \\
\hline S29 & 11.54 & \pm & 1.00 & 5.7 & \pm & 0.1 & 43 & \pm & 7 & 5.7 & \pm & 0.1 & 10.79 & \pm & 0.41 \\
\hline S10 & 6.67 & & & 4.2 & & & 105 & & & 5.0 & & & 8.33 & & \\
\hline S27 & 3.17 & & & 3.7 & & & 156 & & & 4.8 & & & 10.08 & & \\
\hline DSM2601 & 3.75 & & & 3.7 & & & 150 & & & 4.8 & & & 10.50 & & \\
\hline
\end{tabular}




\section{FIGURE LEGENDS}

Figure 1

Acidification profile $\left(\mathrm{dpH} / \mathrm{dt}\right.$ ) obtained from three isolates grown in $\mathrm{BHI}$ (initial $\mathrm{pH} 6.8$ ) at $37^{\circ} \mathrm{C}$. Black line: S12 W. cibaria; Grey line: S17 Lb. plantarum/pentosus; Bold line: S13 Leuc. holzapfelii/citreum Figure 2

Principal component analysis of isolates (observations). Variables are acidification profile parameters: $\mathrm{Tm}, \mathrm{Vm}, \mathrm{pHm}, \mathrm{pHmin}$ and lag time.

Figure 3

Growth of isolates over $48 \mathrm{~h}$ at $30^{\circ} \mathrm{C}$. A: OD $600 \mathrm{~nm}$ variation in $\mathrm{BHI}$; B: relative $\mathrm{OD} 600 \mathrm{~nm}$ variation in the presence of oxidative stress. Grey bar: $\mathrm{H}_{2} \mathrm{O}_{2} 0.025 \%$; black bar: $\mathrm{H}_{2} \mathrm{O}_{2} 0.05 \%$. C: relative OD $600 \mathrm{~nm}$ variation in the presence of acid ( $\mathrm{pH} 4.5)$ or salt ( $5 \% \mathrm{NaCl}$ ) stress. Grey bar: $\mathrm{pH} 4.5$; black bar: $\mathrm{NaCl}$

$5 \%{ }^{*} \mathrm{p}<0.05 ;{ }^{* *} \mathrm{p}<0.01 ;{ }^{* * *} \mathrm{p}<0,001$ compared to control condition $(\mathrm{BHI}, 100 \%)$.

Figure 4

Antioxydant activity of pineapple juice after $48 \mathrm{~h}$ incubation at $25^{\circ} \mathrm{C}$, without or with indicated isolate. A: Folin-Ciocalteau values, expressed as GAE g. $\mathrm{L}^{-1} ; \mathrm{B}$ : LDL oxidation kinetics for isolate $\mathrm{S} 27$. V50 values are shown by arrows. ${ }^{* *} p<0.01$ compared to control condition (juice).

Figure S1

Dendrogram for Weissella spp isolates and reference strains using $(\mathrm{GTG})_{5}$ genotyping. See materials and methods for cluster analysis and tree building. 
Figure 1

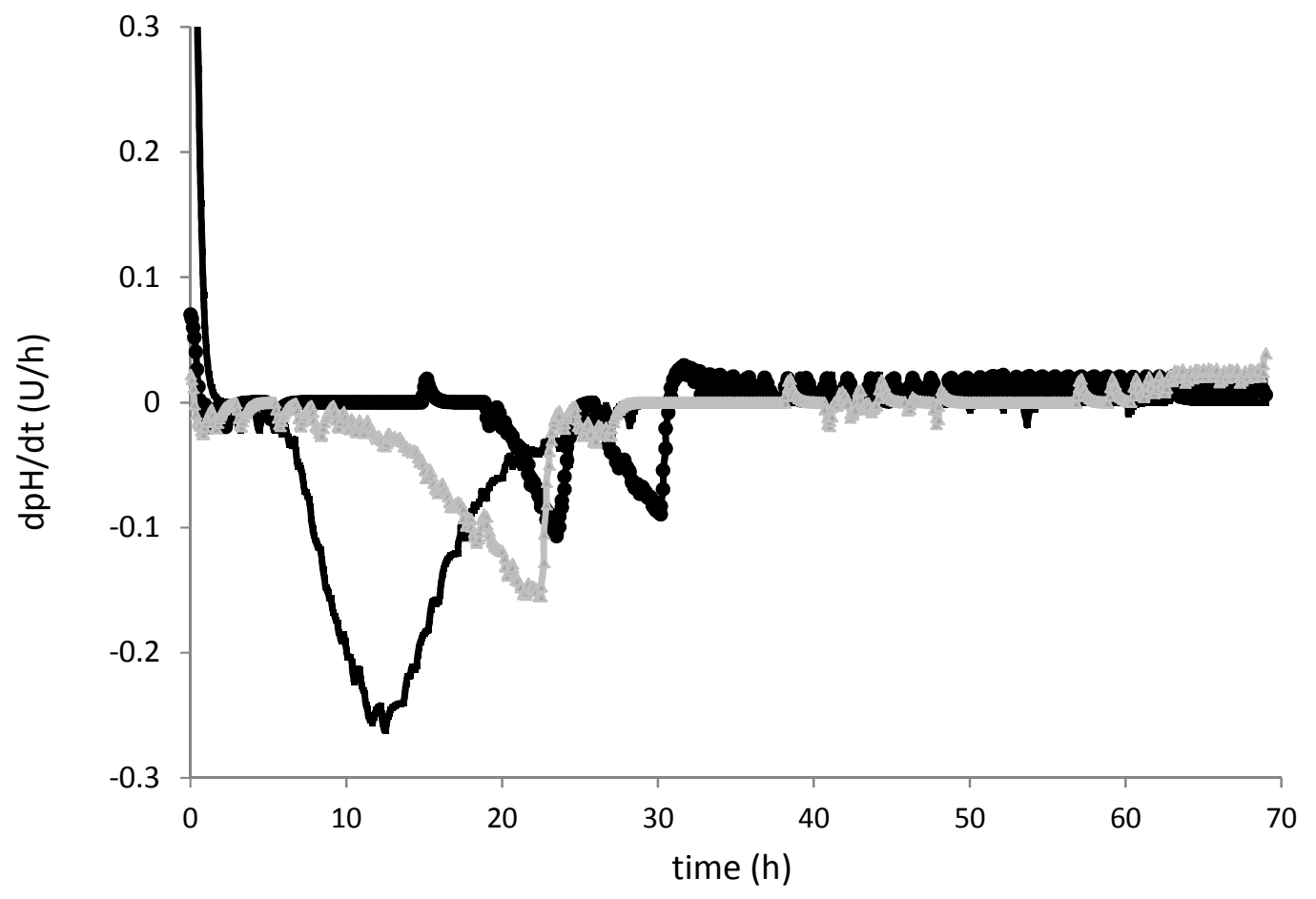


Figure 2

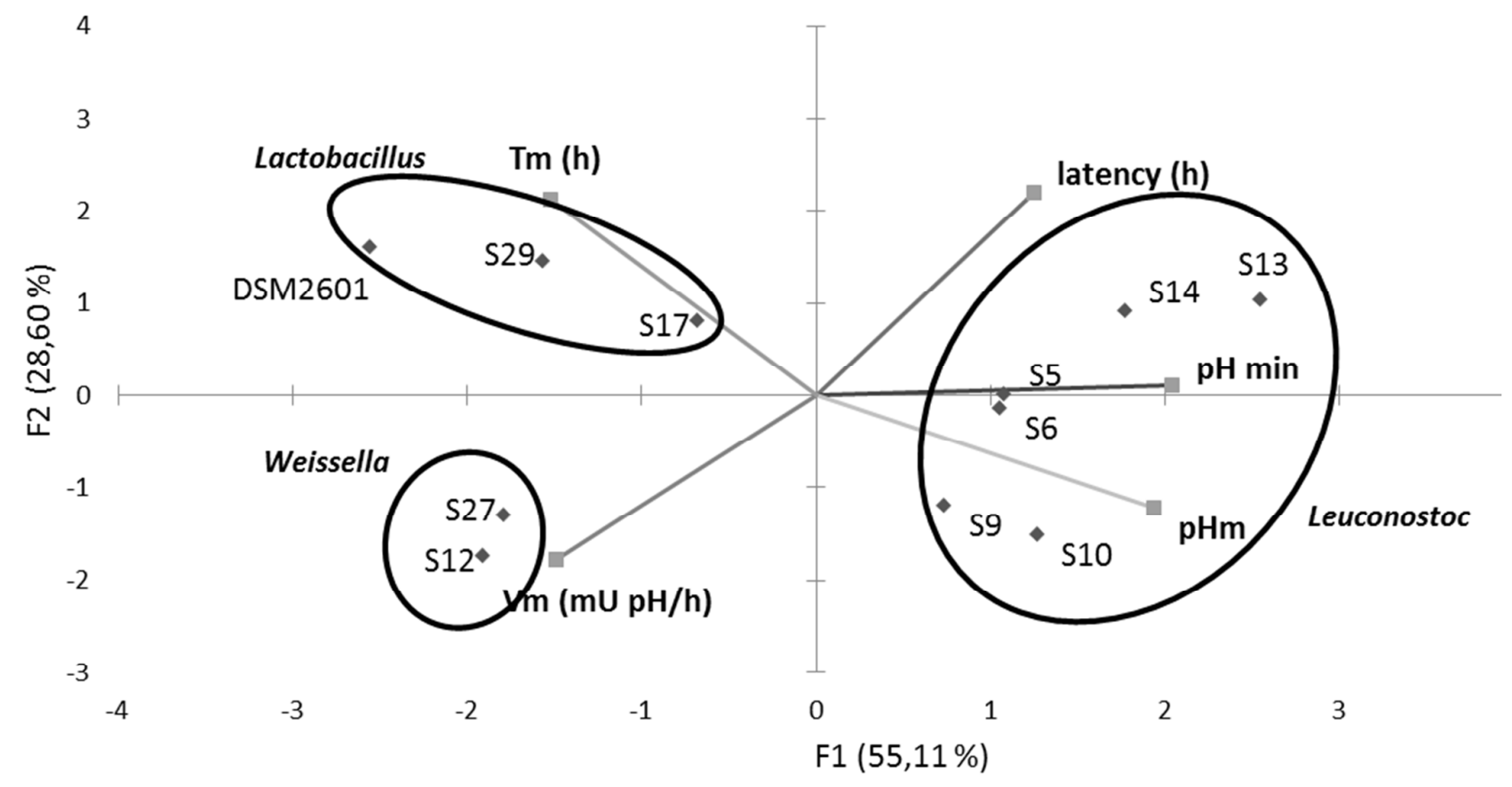


Figure 3

A

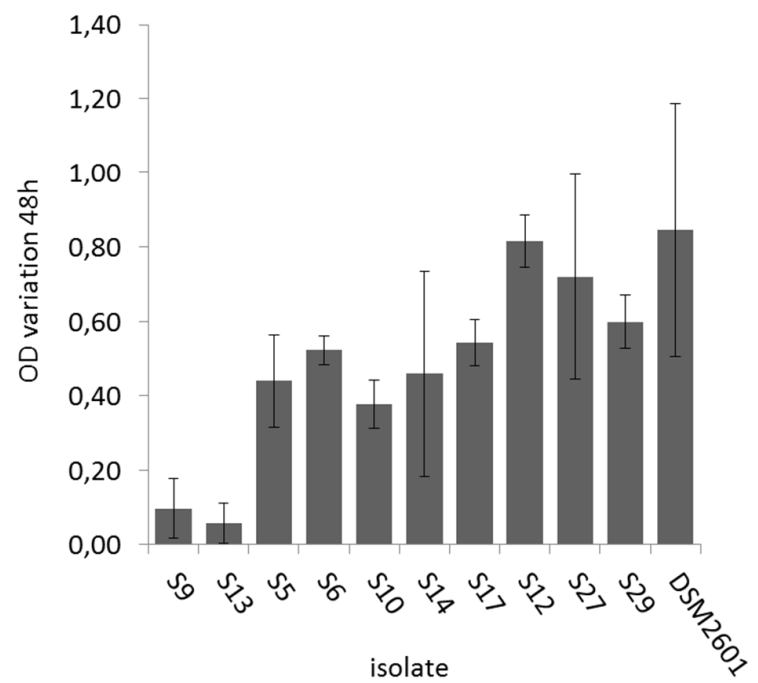

B

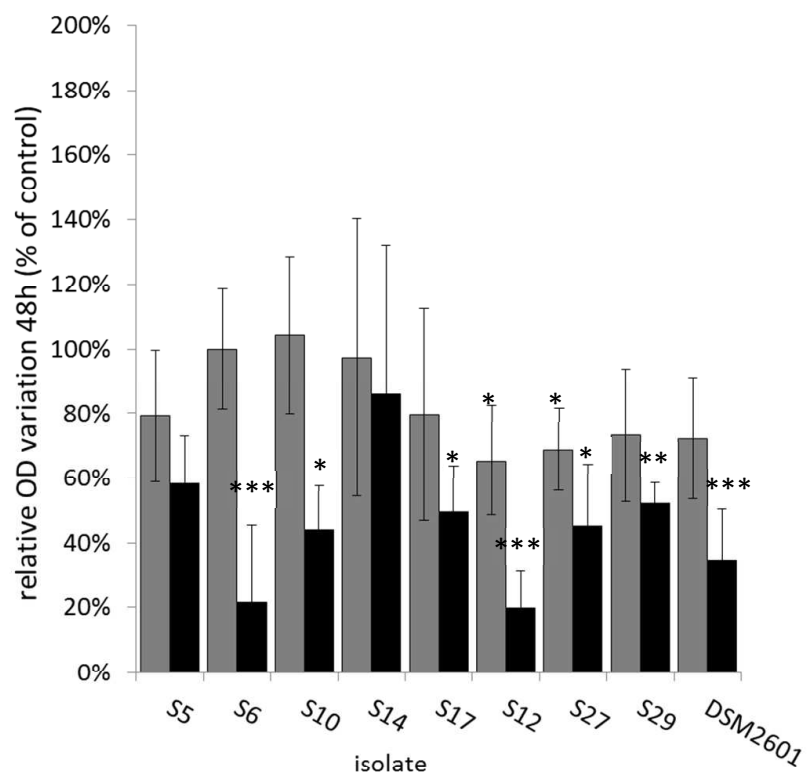

C

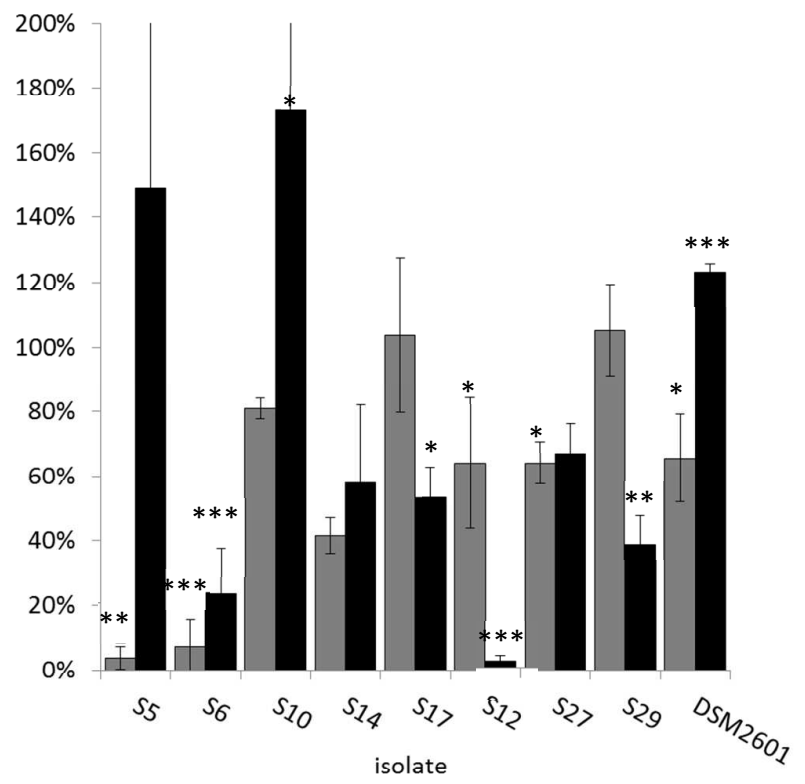


Figure 4

A

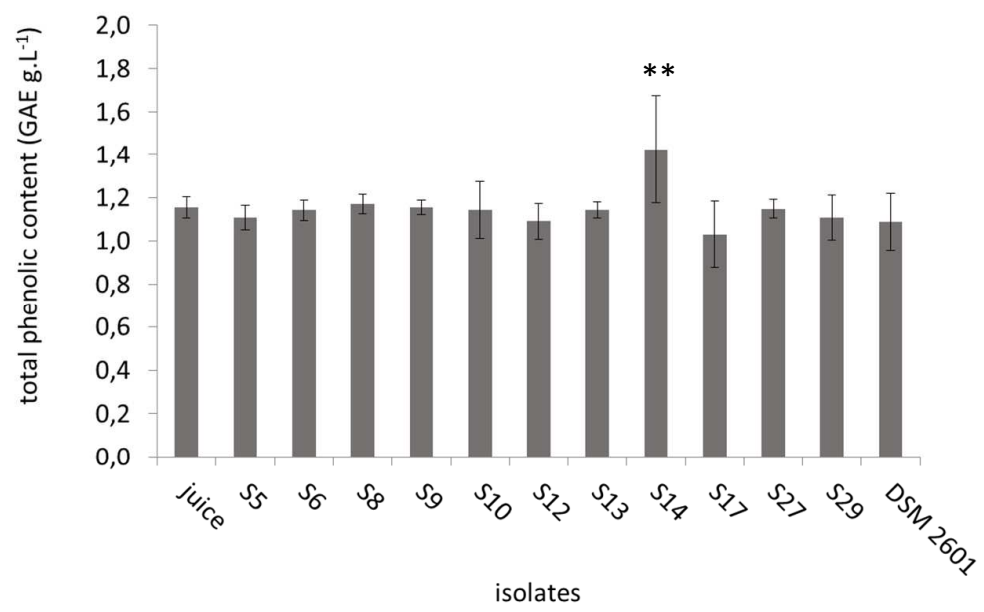

B

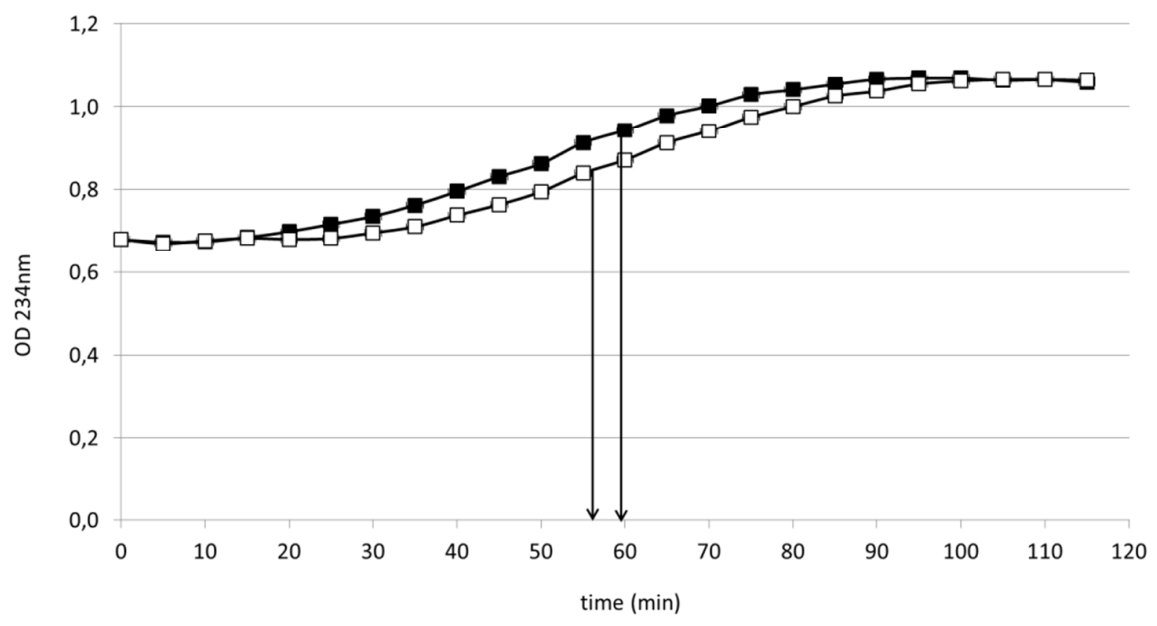

